\title{
Pertumbuhan Jintan Hitam (Nigella sativa L.) pada Tingkat Naungan dan Pemupukan Nitrogen yang Berbeda
}

\author{
Growth of Black Cumin (Nigela sativa L.) at Different Shading and Nitrogen Rates
}

\author{
Evi Setiawati ${ }^{1}$, Ani Kurniawati ${ }^{2 *}$, Winarso D. Widodo ${ }^{2}$, dan Didah Nur Faridah ${ }^{3}$ \\ ${ }^{1}$ Program Studi Agronomi dan Hortikultura, Sekolah Pascasarjana, Institut Pertanian Bogor \\ ${ }^{2}$ Departemen Agronomi dan Hortikultura, Fakultas Pertanian, Institut Pertanian Bogor \\ (Bogor Agricultural University), Jl. Meranti, Kampus IPB Darmaga, Bogor 16680, Indonesia \\ ${ }^{3}$ Department Teknologi Pangan, Fakultas Teknologi Pertanian, Institut Pertanian Bogor \\ (Bogor Agricultural University), Jl. Meranti, Kampus IPB Darmaga, Bogor 16680, Indonesia
}

Diterima 15 Agustus 2017/Disetujui 19 Juli 2018

\begin{abstract}
Black cumin (Nigella sativa L.) is an introduced medicinal plant and therefore requires investigations to establish recommended cultivation procedure in tropical areas. Black cumin seeds contain various bioactive compounds not only for culinary but also for medicinal purposes. This study was conducted to investigate the effect of nitrogen rates and shade levels on growth of black cumin. The activity was carried out in Pasir Sarongge experimental station, Cianjur, West Java (1,117 masl). The research was arranged in a nested design with three replications. Nitrogen rates was nested within shading levels. The shading levels consisted of $0 \%, 25 \%, 50 \%$, and 75\% which resulted in light intensity of 27,800, 17,400, 11,900, and 1,600 lux respectively. The nitrogen rates consisted 0, 60, 120, and $180 \mathrm{~kg} \mathrm{ha}$. The results showed that shading up to $50 \%$ did not affect plant growth and did not reduce seed production. However, shading up to $75 \%$ prolong the vegetative period, decreased leaf thickness and plant dry weight. The higher the shading level up to 50\%, the higher the plant height, leaf area, number of leaves and number of flower, but not number of branches. Nitrogen fertilizer at $60 \mathrm{~kg} \mathrm{ha-1}$ increased number of blooming flower and number of capsule set.
\end{abstract}

Keywords: flowering, high altitude, leaf, tropic

\section{ABSTRAK}

Jintan hitam (Nigella sativa L.) merupakan tanaman obat introduksi yang memerlukan kajian untuk merakit standar budidaya di wilayah tropika. Biji jintan hitam mengandung berbagai senyawa bioaktif untuk tujuan pengobatan selain untuk kuliner. Penelitian bertujuan untuk mempelajari pertumbuhan jintan hitam pada beberapa intensitas naungan dan dosis pupuk nitrogen. Penelitian dilaksanakan di Kebun Percobaan, Pasir Sarongge, Cianjur, Jawa Barat (1,117 mdpl). Rancangan percobaan menggunakan petak tersarang (nested design) dengan 3 ulangan. Dosis pupuk nitrogen tersarang pada taraf naungan. Taraf naungan terdiri atas 4 taraf yaitu 0\%, 25\%, 50\%, dan 75\% dengan intesitas cahaya berturutturut 27,800, 17,400, 11,900, dan 1,600 lux. Dosis pupuk nitrogen terdiri atas 0, 60, 120, dan $180 \mathrm{~kg} \mathrm{ha}^{-1}$. Hasil percobaan menunjukkan bahwa naungan sampai dengan 50\% tidak berpengaruh pada pertumbuhan dan tidak menurunkan produksi benih, namun naungan sampai dengan 75\% memperpanjang masa vegetatif, menurunkan ketebalan daun dan bobot brangkasan tanaman. Naungan sampai 50\% meningkatkan tinggi tanaman, jumlah daun, luas daun, dan jumlah bakal bunga

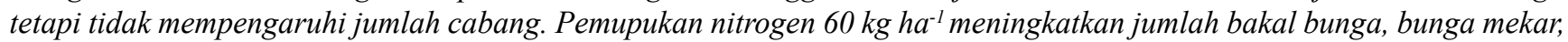
dan jumlah kapsul terbentuk.

Kata kunci: bunga, dataran tinggi, daun, tropika

\section{PENDAHULUAN}

Indonesia memenuhi kebutuhan jintan hitam melalui impor dari India dan Mesir serta negara Timur Tengah

\footnotetext{
* Penulis untuk korespondensi. e-mail: ani_kurniawati@apps.ipb. ac.id
}

lainnya. Total impor jintan hitam oleh Indonesia meningkat dari tahun 2015 ke 2016. Impor jintan hitam pada tahun 2015 sebanyak 2,166,499 kg dengan nilai 2,194,068 US\$ meningkat menjadi $2,368,021 \mathrm{~kg}$ dengan nilai $2,626,383$ US\$ pada tahun 2016 (BPS, 2016).

Jintan hitam tumbuh pada tanah berpasir, lempung kaya aktivitas mikroba dengan $\mathrm{pH}$ tanah 7.0-7.5 (Datta et 
al., 2012), di Jordan pada ketinggian 530-800 m dpl, suhu rata-rata $6.9-21.4{ }^{\circ} \mathrm{C}$ dan curah hujan $319.2-462.5 \mathrm{~mm}$ per tahun (Talafih et al., 2007) dan di daerah Moroko utara, suhu rata-rata $17.4{ }^{\circ} \mathrm{C}$ dengan curah hujan $0-600 \mathrm{~mm}$ (Gharby et al., 2013). Indonesia sebagai wilayah tropika mempunyai suhu, kelembaban, dan curah hujan lebih tinggi dengan tingkat kemasaman tanah yang lebih rendah. Perbedaan agroklimatologi dan edafik diduga akan mempengaruhi pertumbuhan jintan hitam.

Pemupukan nitrogen penting untuk pertumbuhan dan perkembangan tanaman terutama pada masa vegetatif yang berperan dalam pembentukan protein dan enzim. Pemupukan $\mathrm{N}$ dan $\mathrm{P}$ meningkatkan pertumbuhan jintan hitam, indeks panen, presentase minyak pada benih (Rana et al., 2012), serta produksi benih (Talafih et al., 2007).

Peningkatan luas konversi lahan pertanian ke non pertanian sekitar 50-100 ribu hektar setiap tahun (Kementan, 2015) membuat perlunya dilakukan inovasi teknologi budidaya tanaman di bawah tegakan seperti tumpang sari atau agroforestri.

Kebutuhan hara pada budidaya di lahan terbuka berbeda dengan di bawah naungan. Semakin tinggi taraf naungan semakin rendah jumlah nitrogen yang diserap tanaman. Peningkatan taraf naungan mengakibatkan cahaya yang diterima oleh tanaman semakin berkurang dan menyebabkan perkembangan akar akan berkurang dibandingkan dengan tanaman yang menerima cahaya penuh (Sirait et al., 2005). Intensitas cahaya rendah juga menyebabkan penurunan fotosintat yang menyebabkan konsentrasi nitrogen meningkat dalam tanaman Dactylis glomerata (Abraham et al., 2014) dan talas (Djukri dan Purwoko, 2003).

Jintan hitam di Indonesia berpeluang besar ditanam di bawah tegakan tanaman lain. Hal ini juga karena makin sulitnya mendapatkan lahan di dataran tinggi serta persaingan dengan komoditas dataran tinggi. Oleh karena itu, tujuan penelitian adalah untuk mendapatkan dosis pupuk nitrogen dan tingkat intensitas cahaya yang tepat untuk mendukung pertumbuhan tanaman jintan hitam.

\section{BAHAN DAN METODE}

Percobaan lapang dilakukan pada bulan Juni sampai November 2016 di Kebun Percobaan IPB, Pasir Sarongge, Jawa Barat, dengan ketinggian tempat 1,117 m dpl. Percobaan menggunakan rancangan petak tersarang (nested design). Dosis pupuk nitrogen tersarang pada taraf naungan yang terdiri atas 4 taraf yaitu 0 (cahaya penuh), 25 , 50, dan $75 \%$ dengan hasil intesitas cahaya rata-rata secara berurutan 27,800,17,400, 11,900, dan 1,600 lux. Dosis pupuk nitrogen terdiri atas $0,60,120$, dan $180 \mathrm{~kg} \mathrm{ha}^{-1}$. Setiap perlakuan diulang sebanyak 3 kali, sehingga terdapat 48 satuan percobaan, setiap satuan percobaan terdiri atas 4 tanaman contoh. Peubah yang diamati adalah tinggi tanaman, jumlah cabang, jumlah daun, ketebalan daun, luas daun, waktu berbunga, jumlah bunga, jumlah kapsul dan bobot brangkasan tanaman. Data yang diperoleh dianalisis menggunakan uji $\mathrm{F}$ taraf 5\%. Bila berbeda nyata dilanjutkan dengan uji jarak berganda Duncan (Duncan's multiple range test) taraf 5\%.

\section{HASIL DAN PEMBAHASAN}

\section{Taraf Nitrogen}

Naungan 75\% meningkatkan tinggi tanaman (Tabel 1). Tanaman jintan hitam di bawah naungan $75 \%$ mengalami etiolasi yang ditunjukkan dengan kenaikan tinggi tanaman namun tidak kokoh. Intensitas cahaya rendah menyebabkan gangguan translokasi karbohidrat, gula total (sebagian besar gula nonreduksi) dan pati menurun pada seluruh bagian tanaman (Sopandie dan Trikoesoemaningtyas, 2011).

Tinggi tanaman jintan hitam dalam penelitian ini lebih tinggi dibandingkan dengan penelitian sebelumnya yang mencapai $23.0 \mathrm{~cm}$ (Suryadi et al., 2015) dan 28.63 $\mathrm{cm}$ (Ridwan et al., 2014) namun masih lebih rendah dibandingkan dengan tinggi jintan hitam di Turki yaitu $34.68-40.68 \mathrm{~cm}$ (Tuncturk et al., 2005), 41.12-68.51 cm di India (Malhotra dan Vashishtha, 2008; Shah dan Tak, 2011), 58-100 cm di Iran (Valadabadi dan Farahani, 2011), dan 42.2-91.46 cm di Mesir (Hendawy et al., 2012; ElMekawy, 2012). Perbedan aksesi dan lingkungan tumbuh antara negara tropis dan mediterania diduga mempengaruhi perbedaan pertumbuhan tanaman. Secara umum, kondisi di daerah mediterania mempunyai $\mathrm{pH}$ yang lebih basa yaitu, antara 7-8.2, curah hujan yang lebih rendah 116-252.5 nm, suhu harian dan kelembaban yang lebih rendah yaitu 17-22 ${ }^{\circ} \mathrm{C}$ dan 53-66\%.

Peningkatan tinggi tanaman diikuti dengan peningkatan jumlah daun. Jumlah daun dalam penelitian ini yang dihitung adalah daun yang masih hijau atau yang berada pada tanaman. Tanaman dengan naungan $75 \%$ memiliki daun yang masih berada pada buku-buku tanaman, sedangkan pada taraf naungan lain, daun sudah gugur.

Naungan tidak memberikan pengaruh pada jumlah cabang jintan hitam. Sama halnya dengan tinggi tanaman dan jumlah daun, jumlah cabang jintan hitam dalam penelitian ini lebih banyak dibandingkan dengan penelitian sebelumnya yang mempunyai jumlah 4.75 cabang (Suryadi et al., 2015) dan 3.3 cabang (Ridwan et al., 2014). Perbedaan ini diduga karena perbedaan lingkungan tumbuh dan aksesi jintan hitam yang digunakan. Aksesi yang digunakan pada penelitian ini berasal dari Turki, sedangkan pada penelitian sebelumnya yaitu pada penelitian Suryadi et al. (2015) dan Ridwan et al. (2014) berasal dari Arab Saudi.

Pemberian naungan $0 \%$, 25\%, dan 50\% tidak menurunkan ketebalan daun kecuali pada naungan $75 \%$. Penurunan ketebalan daun diduga karena respon tanaman terhadap intensitas cahaya rendah. Menurut Kisman et al. (2008), Li et al. (2010), dan Afa dan Sudarsono (2014), ketebalan daun berhubungan dengan jaringan palisade. Pemendekan jaringan palisade mengakibatkan ketebalan daun semakin menurun.

Tanaman yang ternaungi sampai dengan intensitas 50\% memiliki permukaan daun lebih luas dibandingkan dengan tanaman tanpa naungan (Tabel 1). Hal ini terjadi 
karena adanya mekanisme adaptasi terhadap intensitas cahaya rendah, melalui peningkatan efisiensi penangkapan cahaya dengan perluasan permukaan daun. Hal ini sejalan dengan penelitian Kasai (2008) pada tanaman kacang hijau dan Yao et al. (2016) pada tanaman kapas.

Pemberian naungan 75\% memperlambat waktu muncul bunga tanaman jintan hitam hingga 1 minggu (Tabel 1). Pembungaan tanaman jintan hitam, yang dinaungi sampai dengan intensitas 50\% terjadi pada 8 MST. Menurut Geromel et al. (2008), Widaryanto et al. (2011), Deng et al. (2012) dan Zhao et al. (2012), naungan dapat memperlambat waktu berbunga karena penurunan aktivitas fotosintesis yang tidak mendukung untuk akumulasi produk fotosintesis, khususnya gula terlarut, yang mengakibatkan tidak memadainya pasokan fotosintat untuk perkembangan bunga. Penelitian pada tanaman Paeonia lactiflora (Zhao et al., 2012), melati (Deng et al., 2012), kopi (Geromel et al., 2008), dan jagung (Syafi'i et al., 2014) menunjukkan hasil yang sama.

Jumlah bakal bunga pada naungan $75 \%$ sejalan dengan jumlah kapsul terbentuk. Pemberian naungan dengan intensitas 75\% menyebabkan penurunan jumlah bakal bunga dan jumlah kapsul terbentuk. Hal ini karena cahaya yang diterima oleh tanaman pada naungan tersebut lebih rendah, yang mengakibatkan terjadinya penurunan akumulasi karbohidrat sehingga dapat menyebabkan metabolime tanaman terganggu. Menurut Sopandi et al. (2003), intensitas cahaya yang rendah pada saat pembungaan pada padi menyebabkan penurunan kandungan karbohidrat, protein, auksin, prolin, dan sitokinin.

Tanaman yang ditanam pada intensitas naungan $75 \%$ menghasilkan jumlah kapsul yang lebih sedikit (Tabel 1). Fotosintesis terhambat juga menyebabkan jumlah pasokan fotosintat ke organ generatif menurun pada tanaman kedelai (Hadriawan et al., 2016) dan tanaman vanila (Mansur, 2009).

Naungan menyebabkan terjadinya tumpukan nitrat $\left(\mathrm{NO}_{3}\right)$ pada tanaman yang disebabkan berkurangnya energi yang dibutuhkan oleh enzim nitrat reduktase untuk mereduksi nitrat menjadi nitrit $\left(\mathrm{NO}_{2}\right)$. Energi ini berasal dari hasil reaksi fotosintesis (Sirait, 2008). Gambar 1 menunjukkan penurunan produksi biomas tanaman yang ternaungi yang disebabkan oleh proses fotosintesis yang terhambat.

Pola brangkasan (y) pada tingkat naungan (x) adalah $\mathrm{y}=-0.0003 \mathrm{x} 2+0.0139 \mathrm{x}+1.2075$ dan $\mathrm{R}^{2}=0.9214$ sehingga menghasilkan brangkasan optimal $1.36 \mathrm{~g}$ pada tingkat naungan 23.1\%. Brangkasan jintan hitam menurun hanya jika dinaungi dengan intensitas 75\% (Gambar 1). Penurunan bobot ini serupa dengan hasil penelitian Fanindi et al. (2010), peranan cahaya dalam metabolisme tanaman terhambat yang menyebabkan penurunan biomassa pada Calopogonium mucunoides. Tanaman jintan hitam masih dapat bertahan hingga naungan 50\%, sehingga tanaman ini berpeluang dijadikan sebagai tanaman sela atau tumpang sari.

\section{Pemupukan Nitrogen}

Pemupukan berbagai dosis $\mathrm{N}$ tidak memberikan pengaruh pada tinggi tanaman, jumlah daun, jumlah cabang, dan ketebalan daun (Tabel 2). Penelitian Mansur dan Surahman (2011) pada tanaman jabon juga menghasilkan hal yang serupa. Hal ini diduga karena media tanam yang digunakan mengandung banyak kadar nitrogen dengan jumlah N-Total pada kriteria tinggi yaitu $0.65 \%$. Kriteria kadar N-total tinggi apabila mengandung 0.51-0.75\% (Balittanah, 2009).

Pemupukan $\mathrm{N}$ sebesar $60 \mathrm{~kg} \mathrm{ha}^{-1}$ hanya meningkatkan jumlah bunga mekar dan jumlah kapsul terbentuk yang kemudian menurun pada 120 dan $180 \mathrm{~kg} \mathrm{ha}^{-1}$ (Tabel 2). Hal ini karena media yang digunakan sudah mengandung nitrogen dengan kriteria tinggi $(0.65 \%)$ yang mampu mendukung perkembangan tanaman. Berbeda dengan penelitian Suryadi et al. (2017) kadar N-total pada kriteria rendah yaitu $0.2 \%$ sehingga pemupukan $\mathrm{N}$ mampu meningkatkan semua komponen hasil pada tanaman jintan hitam.

Tabel 1. Tinggi tanaman, jumlah daun, jumlah cabang (13 MST*), ketebalan daun (12 MST*), luas daun (14 MST*), dan fase generatif jintan hitam pada beberapa taraf naungan

\begin{tabular}{lcccc}
\hline \multirow{2}{*}{ Peubah } & \multicolumn{3}{c}{ Naungan (\%) } \\
\cline { 2 - 5 } & 0 & 25 & 50 & 75 \\
\hline Tinggi tanaman $(\mathrm{cm})$ & $32.13 \mathrm{c}$ & $37.44 \mathrm{~b}$ & $39.44 \mathrm{ab}$ & $40.76 \mathrm{a}$ \\
Jumlah daun (helai) & $27.21 \mathrm{~b}$ & $32.38 \mathrm{ab}$ & $34.59 \mathrm{a}$ & $35.55 \mathrm{a}$ \\
Jumlah cabang & 13.60 & 14.40 & 14.00 & 12.00 \\
Ketebalan daun $(\mu \mathrm{m})$ & $282.39 \mathrm{a}$ & $254.61 \mathrm{a}$ & $273.23 \mathrm{a}$ & $211.70 \mathrm{~b}$ \\
Luas daun $\left(\mathrm{cm}^{2}\right)$ & $126.90 \mathrm{~b}$ & $178.38 \mathrm{a}$ & $173.58 \mathrm{a}$ & $168.93 \mathrm{a}$ \\
\hline Awal berbunga penuh $\left(\mathrm{MST}^{*}\right)$ & $8.40 \mathrm{~b}$ & $8.40 \mathrm{~b}$ & $8.60 \mathrm{~b}$ & $9.20 \mathrm{a}$ \\
Jumlah bakal bunga & $7.78 \mathrm{ab}$ & $8.27 \mathrm{a}$ & $7.45 \mathrm{ab}$ & $6.39 \mathrm{~b}$ \\
Jumlah bunga mekar & 2.41 & 2.71 & 2.44 & 2.51 \\
Jumlah kapsul terbentuk & $12.60 \mathrm{a}$ & $13.60 \mathrm{a}$ & $12.10 \mathrm{a}$ & $8.06 \mathrm{~b}$ \\
\hline
\end{tabular}

Keterangan: Angka yang diikuti oleh huruf yang berbeda pada baris yang sama menunjukkan berbeda nyata menurut uji DMRT 5\%; *) Minggu setelah tanam 
Tabel 2. Tinggi tanaman, jumlah daun, jumlah cabang (13 MST*), ketebalan daun (12 MST*), luas daun (14 MST*), dan fase generatif jintan hitam pada beberapa taraf pemupukan nitrogen

\begin{tabular}{lcccc}
\hline \multirow{2}{*}{ Peubah } & \multicolumn{3}{c}{ Pupuk N $\left(\mathrm{kg} \mathrm{ha}^{-1}\right)$} \\
\cline { 2 - 5 } & 0 & 60 & 120 & 380 \\
\hline Tinggi tanaman $(\mathrm{cm})$ & 37.38 & 38.15 & 35.97 & 38.27 \\
Jumlah daun (helai) & 33.19 & 36.25 & 30.65 & 29.64 \\
Jumlah cabang & 13.30 & 14.90 & 13.10 & 12.90 \\
Ketebalan daun $(\mu \mathrm{m})$ & 250.62 & 246.66 & 253.13 & 271.53 \\
Luas daun $(\mathrm{cm}$ ) & $183.45 \mathrm{a}$ & $133.82 \mathrm{~b}$ & $153.16 \mathrm{ab}$ & $177.36 \mathrm{a}$ \\
\hline Awal berbunga penuh (MST*) & $8.8 \mathrm{ab}$ & $8.40 \mathrm{~b}$ & $9.00 \mathrm{a}$ \\
Jumlah bakal bunga & 7.65 & 7.84 & 7.08 & 7.32 \\
Jumlah bunga mekar & $2.41 \mathrm{~b}$ & $2.87 \mathrm{a}$ & $2.48 \mathrm{~b}$ & $2.29 \mathrm{~b}$ \\
Jumlah kapsul terbentuk & $11.50 \mathrm{~b}$ & $13.20 \mathrm{a}$ & $10.60 \mathrm{~b}$ & $11.10 \mathrm{~b}$ \\
\hline
\end{tabular}

Keterangan: Angka yang diikuti oleh huruf yang berbeda pada baris yang sama menunjukkan berbeda nyata menurut uji DMRT 5\%; *) Minggu setelah tanam

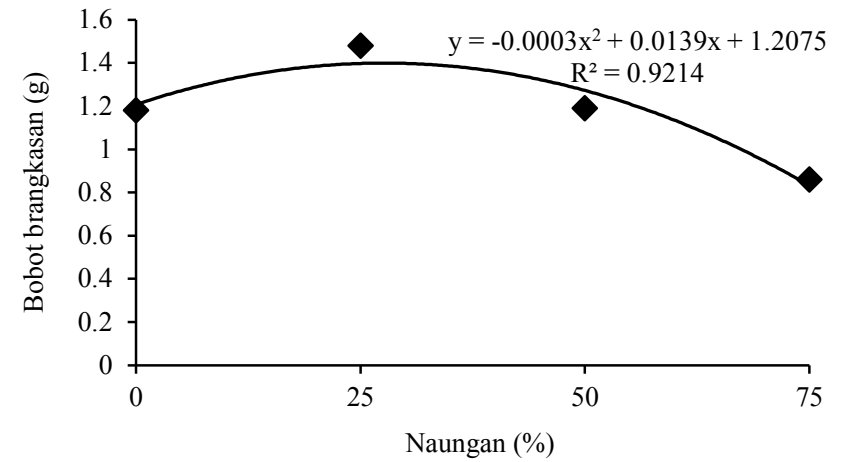

Gambar 1. Pola respon bobot brangkasan jintan hitam terhadap perbedaan taraf naungan

\section{KESIMPULAN}

Jintan hitam mampu tumbuh pada naungan $0 \%, 25 \%$, dan $50 \%$. Naungan $75 \%$ memperpanjang masa vegetatif. Tingkat naungan yang semakin tinggi akan meningkatkan tinggi tanaman, jumlah daun, luas daun, dan jumlah bakal bunga, namun menurunkan jumlah kapsul terbentuk, ketebalan daun, dan bobot brangkasan tanaman. Pemberian pupuk nitrogen $60 \mathrm{~kg} \mathrm{ha}^{-1}$ mampu meningkatkan jumlah bunga mekar dan jumlah kapsul terbentuk.

\section{UCAPAN TERIMA KASIH}

Terima kasih kepada Dr. Ani Kurniawati, SP, M.Si yang menyediakan sebagian dana penelitian melalui Program Unggulan Perguruan Tinggi (PUPT).

\section{DAFTAR PUSTAKA}

Abraham, E.M., A.P. Kyriazopoulos, Z.M. Parissi, P. Kostopoulou, M. Karatassiou, K. Anjalanidou, C.
Katsouta. 2014. Growth, dry matter production, phenotypic plasticity, and nutritive value of three natural populations of Dactylis glomerata L. under various shading treatments. Agroforest. Syst. 88:287299.

Afa, L.O., W.A. Sudarsono. 2014. Pengaruh naungan terhadap pertumbuhan dan hasil tanaman kolesom (Talinum triangule (Jacq.) Willd). Agriplus. 24:144151.

[Balittanah] Balai Penelitian Tanah. 2009. Petunjuk Teknis edisi 2 Analisis Kimia Tanah, Tanaman, Air dan Pupuk. Balai Penelitian Tanah, Bogor, ID.

[BPS] Badan Pusat Statistik. 2016. Statistik Perdangangan Luar Negeri - Impor 2016 Jilid I. Badan Pusat Statistik, Jakarta, ID.

Datta, A.K., A. Saha, A. Bhattacharya, A. Mandal, R. Paul, S. Sonali. 2012. Black cumin (Nigella sativa L.) - a review. JPDS. 4:1-43.

Deng, Y., Q. Shao, C. Li, X. Ye, R. Tang. 2012. Differential responses of double petal and multi petal jasmine to shading: II morphology, anatomy, and physiology. Sci Hort. 144:19-28.

Djukri, B.S. Purwoko. 2003. Pengaruh naungan paranet terhadap sifat toleransi tanaman talas (Colocasia esculenta (L.) Schott). Ilmu Pertanian 10:17-25.

El-Mekawy, A. 2012. Growth and yield of Nigella sativa L. plant influenced by sowing date and irrigation treatments. Am. Eurasian J. Agric. Environ. Sci. 12:499-505. 
Fanindi, A., B.R. Prawiradiputra, L. Abdullah. 2010. Pengaruh intensitas cahaya terhadap produksi hijauan dan benih kalopo (Calopogonium mucunoides). JITV. 15:205-214

Geromel, C., L.P. Ferreira, F. Davrieux, B. Guyot, F. Ribeyre, M.B.S. Scholz, L.F.P. Pereira, P. Vaast, D. Pot, T. Leroy, A.A. Filho, L.G.E. Vieira, P. Mazzafera, P. Marraccini. 2008. Effects of shade on the development and sugar metabolism of coffee (Coffea arabica L.) fruits. Plant Physiol. Biochem. 46:569-579.

Gharby, S., H. Harhar, D. Guillaume, A. Roudani, S. Boulbaroud, M. Ibrahimi, M. Ahmad, S. Sultana, T. Ben-Hadda, I. Chafchaouni-Moussaoui, Z. Charrouf. 2013. Chemical investigation of Nigella sativa L. seed oil produced in Morocco. J. Saudi Soc. Agri. Sci. 14:172-177.

Hadriawan, A., D.W. Respatie, Tohari 2016. Pengaruh intensitas naungan terhadap pertumbuhan dan hasil tiga kultivar kedelai (Glycine $\max$ (L.) Merrill) di lahan pasir Pantai Bugel, Kulon Progo. Vegetalika 5:1-14.

Hendawy, S.F., S.E. El-Sherbeny, M.S. Hussein, K.A. Khalid, G.M. Ghaal. 2012. Response of two species of black cumin to foliar spray treatments. Aust. J. Basic. Appl. Sci. 6:636-642.

Kasai, M. 2008. Effect of growing soybean plants under continous light on leaf photosynthethic rate and other characteristics concerning biomass production. J. Agronomy 7:156-162.

[Kementan] Kementerian Pertanian. 2015. Rencana Strategis Kementerian Pertanian 2015-2019. Kementerian Pertanian, Jakarta, ID.

Kisman, Trikoesoemaningtyas, Sobir, N. Khumaida, D. Sopandie. 2008. Pola pewarisan adaptasi kedelai (Glycine max L. Merrill) terhadap cekaman naungan berdasarkan karakter morfo-fisiologi daun. Bul. Agron. 36:1-7.

Li, H., D. Jiang, B. Wollenweber, T. Dai, W. Cao. 2010. Effects of shading on morphology, physiology and grain yield of winter wheat. Europ. J. Agron. 33:267275.

Malhotra, S.K., B.B. Vashishtha. 2008. Response of nigella (Nigella sativa L.) variety NRCSS AN I to different agr-techniques. JOSAC. 17(2):190-193.
Mansur, I., Surahman. 2011. Respon tanaman jabon (Anthocephalus cadamba) terhadap Pemupukan Lanjutan (NPK). J. Silvikultur Trop. 3:71-77.

Mansur, U. 2009. Teknik penggunaan naungan paranet untuk meningkatkan pertumbuhan dan produksi vanili (Vanilla planifolia Andrews). Bul. Teknik Pertanian 14:76-79.

Rana, S., P.P. Singh, I.S. Naruka, S.S. Rathore. 2012. Effect of nitrogen and phosphorus on growth, yield and quality of black cumin (Nigella sativa L.). ISSS. 2:58 .

Ridwan, T., M. Ghulamahdi, A. Kurniawati. 2014. Laju pertumbuhan dan produksi jintan Hitam (Nigella sativa L.) dengan aplikasi pupuk kandang sapi dan fosfat alam. J. Agron. Indonesia 42:158-165

Shah, S.H., H.I. Tak. 2011. Evaluation of soaking and spray treatments with $\mathrm{GA}_{3}$ to black cumin (Nigella sativa L.) in relation to growth, seed oil yield. Genet. Plant Physiol. 1:119-129.

Sirait, J. 2008. Luas daun, kandungan klorofil dan laju pertumbuhan rumput pada naungan dan pemupukan yang berbeda. JITV. 13:109-116.

Sirait, J., N.D. Purwantari, K. Simanihuruk. 2005. Produksi dan serapan nitrogen rumput pada naungan dan pemupukanyang berbeda. JITV. 10:175-181.

Sopandie, D., M.A. Chozin, S. Sastrosumarjo, T. Juhaeti, Sahardi. 2003. Toleransi padi gogo terhadap naungan. Hayati 10:71-75.

Sopandie, D., Trikoesoemaningtyas. 2011. Pengembangan tanaman sela di bawah tegakan tanaman tahunan. Iptek Tanaman Pangan 6:168-182.

Suryadi, R., M. Ghulamahdi, A. Kurniawati. 2015. Respon pertumbuhan dan produksi jintan hitam (Nigella sativa L.) dengan pemupukan nitrogen dan fosfor. J. Agron. Indonesia 43:227-234.

Suryadi, R., M. Ghulamahdi, A. Kurniawati. 2017. Pemupukan nitrogen dan fosfor untuk meningkatkan pertumbuhan, produksi biji dan kandungan thymoquinone jintan hitam. Bul. Littro. 28:15-28.

Syafi'i, M., B. Waluyo, A.T. Makkulawu, E. Suryadi, Y. Yuwariah, D. Ruswandi. 2014. Identifikasi galur jagung unpad toleran naungan pada sistem agroforestri dengan albizia di Jawa Barat dengan metode GGE biplot. Seminar Nasional Perhimpunan Agronomi Indonesia Penguatan Ketahanan Pangan dalam Menghadapi Perubahan Iklim. Surakarta 1314 November 2014. 
Talafih, K.A., N.I. Haddad, B.I. Hattar, K. Kharallah. 2007. Effect of some agricultural practices on the productivity of black cumin (Nigella sativa L.) grown under rainfed semi-arid conditions. JJAS. 3:385-397.

Tuncturk, M., Z. Ekin, D. Turkozu. 2005. Response of black cumin (Nigellla sativa L.) to different seed rates growth yield components and essential oil content. J. Agron. 4:216-219.

Valadabadi, S.A., H.A. Farahani. 2011. Investigation of biofertilizers influence on quantity and quality characteristics in Nigella sativa L. JHF. 3:88-92.

Widaryanto, E., C. Udayana, M. Baskara, R. Umiarti. 2011. Studi Pertumbuhan Dan Pembungaan
Tiga Jenis Impatiens wallerana pada Berbagai Tingkat Naungan. Seminar Nasional Perhimpunan Hortikultura Kemandirian Produk Hortikultura untuk Memenuhi Pasar Domestik dan Ekspor. Bandung 2324 November 2011.

Yao, H., Y. Zhang, X. Yi, X. Zhang, W. Zhang. 2016. Cotton responds to different plant population densities by adjusting specific leaf area to optimize canopy photosynthetic use efficiency of light and nitrogen. Field Crops Res. 188:10-16.

Zhao, D., Z. Hao, J. Tao. 2012. Effects of shade on plant growth and flower quality in the herbaceous peony (Paeonia lactiflora Pall.). Plant Physiol. Biochem. 61:187-196. 